Sonja Mei Tin Huang*

ORCID: 0000-0001-9782-1566

New Taipei City, Taiwan

\title{
An Asian Perspective on Chiara Lubich and her Pedagogy of Fraternity: \\ An Example of the Course "Culture of Unity" in Higher Education in Taiwan
}

\section{Pedagogia braterstwa Chiary Lubich z perspektywy azjatyckiej. Przykład akademickiego kursu „Kultura Jedności” na Tajwanie}

\begin{abstract}
Summary: As founder of the Focolare Movement, Chiara Lubich was greatly influenced by various fields and disciplines. Her thinking offers a platform of common ground for dialogue. The fundamental elements of Chiara's dialogue are the concepts of love and fraternity, which not only help the Catholic Church to have dialogue with other cultures and religions, but are also relevant to the academic world and our daily life. Chiara's thoughts on unity offer a fresh new perspective; once we have adapted our thinking to this, then a new kind of education becomes possible. Her spirituality of unity - introduced to Asia in 1966 - has been influential

* Dr. Sonja Mei Tin Huang is now Assistant Research Fellow/Assistant Professor as well as Director of Monumenta Serica Sinological Research Center at Fu Jen Academia Catholica, Fu Jen Catholic University, Taiwan. Address: No. 510, Zhonhzheng Rd. 242 Xinzhuang, New Taipei City, Taiwan, R.O.C. Fu Jen Academia Catholica, Fu Jen Catholic University; e-mail: 043726@mail.fju.edu.tw.
\end{abstract}


despite the fact that most of the population are non-Christian. Recently, some Asian scholars have been exploring new approaches using Chiara's philosophy to improve their research methodology and teaching; in Taiwan, the "Culture of Unity" course has experimented with new educational techniques influenced by Chiara's thinking. This paper aims to examine Chiara's thoughts on education, as well as her influence on higher education in Taiwan.

Keywords: Chiara Lubich; Pedagogy of Fraternity; Culture of Unity; Chiara and Asia.

Streszczenie: Chiara Lubich jako założycielka Ruchu Focolari miała ogromny wpływ na kształtowanie się różnych sfer życia i dyscyplin naukowych. Jej myśl stanowi platformę oraz wspólny grunt dla dialogu. Według niej podstawą porozumienia jest miłość i wspólnota, które nie tylko ułatwiają Kościołowi katolickiemu podejmowanie dialogu z innymi kulturami i religiami, lecz również oddziałują na świat akademicki oraz nasze życie codzienne. Spojrzenie Lubich na jedność podpowiada drogę odnowy naszego sposobu myślenia. Odnowienie sposobu myślenia jest początkiem procesu edukacyjnego. Jej duchowość jedności dotarła do Azji w 1966 r. W Azji, gdzie chrześcijaństwo dla większości ludzi jest religią obcą, jej ideał ma szczególnie ważne znaczenie i wpływa na tworzenie jedności między ludźmi. W ostatnich latach azjatyccy naukowcy starają się popularyzować myśl Lubich jako nowy rodzaj metodologii na polu badań i nauczania. Kurs „Kultura Jedności” bazujący na myśli mistyczki został zaproponowany na Tajwanie jako sposób rozpowszechniania nowych możliwości edukacyjnych. Ten artykuł ma na celu zbadanie spojrzenia Lubich na edukację oraz jej wpływu na szkolnictwo wyższe na Tajwanie.

Słowa kluczowe: Chiara Lubich; pedagogia braterstwa; kultura jedności; Lubich i Azja.

Exploring Chiara's influences on education, there are until now few academic articles relating to Chiara Lubich's influence on pedagogy in Asia ${ }^{1}$.

${ }^{1}$ Chiara Lubich (1920-2008), founder of the Focolare Movement, was born in Trento in Italy. She experienced World War II, during which she came to feel that nothing lasts - only God's love remains with people forever; that the Gospel can guide the world towards joyful life and happiness; and that love can bring people together, to work in harmony and have a "real dialogue". 
In 2013, there were three papers presented in the conference Patterns of Unity: An Interdisciplinary Dialogue on the Thought of Chiara Lubich (1920-2008). One was written by Thomas Masters, "Re-Imagining Education through a Spirituality of Communion"; the second was about "Chiara and Life Education in Taiwan"; and the last one was on the topic "Searching for Excellency is Striving for Love"2. All three articles discussed the possible practice of Chiara Lubich's thinking in the education field. Among these three, only the first article - by Thomas Masters - presented an example of how an educator in the United States put Chiara's thinking into practice in her classes; the other two were only hypothetically related to the field of education in Taiwan. It would appear that although those presenters felt that Chiara's spirituality could lend a new dimension to education in Taiwan, it had yet to be put into practice.

Setting aside the question of whether Chiara's thought has influenced the Asian world, it is first worth examining how her spirituality could possibly be connected to Asian culture. This article considers the relationship between Chiara's spirituality and Chinese culture.

Chiara Lubich' spirituality was introduced to Asia in 1966: people throughout the China, Hong Kong, Japan, Korea, Macau, Philippines, Taiwan - as well as in the other Southeast Asian countries ${ }^{3}$ - were attracted by her charisma ${ }^{4}$. Since its first arrival, Chiara's ideal of a "culture of unity" has

2 This 2013 conference was held at Fu Jen Catholic University, Taiwan. It aimed to explore the possible influence of Chiara Lubich's thought on interdisciplinary fields such as theology, education, economy of communion, and interreligious dialogue, as well as the influence of her "culture of unity" on environment, media, culture studies, translation, and psychology. See: Sonja Mei Tin Huang, "The Report on the Conference Patterns of Unity: An Interdisciplinary Dialogue on the Thought of Chiara Lubich (1920-2008)", Catholic Weekly (Tienzhujiao Zhoubao 天主教週報) 12 (28 April, 2013).

3 There have so far been no official publications about the history of the Focolare Movement in Asia, but there are separate publications about the history of the Focolare Movement in different Asian countries. For examples, in Encounter of Unity, the brief history of the Focolare Movement was introduced in the preface; see Encounter of Unity (Heyi de Qiyu 合一的奇遇) (Hong Kong: New City Press, 1955). On 14 March 2015, a 50th anniversary celebration of the Focolare Movement in Asia was held in Manila. For more detail on the history of the Focolare Movement in Asia, see http://www.focolare.org/zh/news/2016/02/19/ asia-50-anni-di-unita/ [accessed 5 June 2018].

${ }^{4}$ Some people joined the Focolare Movement as internal or adherent members. Others do not belong to the Focolare Movement but attend its annual summer gathering, Mariapolis. They are mostly Catholics, Buddhists, or have no particular religion background. "Charisma" means divinely conferred power or talent. 
been embraced by Asian people. It was initially accepted by the Catholic Church, and then by academia. To take Taiwan as an example, in 1997 when Chiara Lubich received an honorary doctoral degree in theology from $\mathrm{Fu}$ Jen Catholic University, it marked the local church's approval of her ideals. She was praised as "the most remarkable woman, and founder of the Focolare Movement, who has considerable influence on the Catholic Church" in the article "The Background and Meaning of Chiara Lubich's Visit to Taiwan," written by the vice president of Fu Jen Catholic University, Fr. Louis Gendron, S.J. ${ }^{5}$ Gendron thought that "her spirituality - culture of unity and interreligious dialogue-aligned completely with the statutes of the Fu Jen College of Theology and the local church in Taiwan" ${ }^{6}$. In 2013, several members of the Focolare Movement who worked at various academic levels of the universities in Taiwan organised the conference Patterns of Unity: An Interdisciplinary Dialogue on the Thought of Chiara Lubich (1920-2008) with the aim of presenting the influence of Chiara's spirituality on various academic fields and its potential relationship with education in Taiwan.

Chiara's spirituality is compatible with Asian cultures: "Christ, the supreme 'Son' of the Father, the Brother of us all, has left us this universal norm: mutual love. He knew it was essential if there were to be peace and unity in the world, and for us all to become a single family" (from Chiara Lubich's talk at UNESCO, 17 December 1996) ${ }^{7}$ captures Chiara's key values. Her perspective had much in common with Asian values, in particular the importance of family, fraternity and unity. In Chiara's view, fraternity (brotherhood) is a key element in building relationships and forging unity

5 See Louis Gendron, “The Background and Meaning of Chiara Lubich's Visit to Taiwan” (Lu Jiale laitai de beijing hen yiyi 盧嘉勒來台的背景和意義), Collectanea Theologica (Shenxue Lunji 神學論集) 111 (2017): 146.

${ }^{6}$ Ibidem, 82. The college of theology of Fu Jen Catholic University has been separated from the university since 2011. Now, it is an independent college known as Fu Jen Faculty of Theology of St. Robert Bellarmine.

7 See Chiara Lubich, Essential Writings (New York: New City Press, 2007), 14 [see also the Italian version: Chiara Lubich, La Dottrina Spirituale (Milan: Mondadori, 2001), 55]. Chiara's point of view was cited by the current president of the Focolare Movement, Maria Voce, in her talk of 12 March 2016 in Castel Gandolfo. She expanded Chiara's idea as "Christians of different Churches, believers of different religions and people of different cultures, all of them are motivated by wanting to enable humankind become one single family" [see http:// www.focolare.org/en/news/2016/03/20/maria-voce-la-cultura-del-dialogo-come-fattore-dipace]. Maria Voce thought that Chiara Lubich put forward a method for education to peace, the "spirituality of unity", which is a new lifestyle that can overcome divisions among individuals. 
among people. The notion of fraternity has long been recognised in Asian culture, which strongly values relationships with family and society. The idea of fraternity in Chinese culture derives from traditional Confucian thought, the dominant philosophy in parts of Asia ${ }^{8}$. Confucianism acknowledges an important concept similar to Chiara's ideal, it is Ren (仁). In Confucian thought, Ren is defined as "wishing to establish oneself, while also seeking to establish others"; Ren could be explained as the notion of mercy in Christianity. For Chiara, mercy means "love towards everyone", because "God was not asking us to love only the poor, but to love each and every neighbour, whoever they were, as we love ourselves (Cf Matt 22:39)". The master of Confucians, Confucius, regarded brotherhood as important ${ }^{9}$, declaring that "within the four seas all men are brothers and sisters"; Confucius's pupil, Mencius, emphasised mutual love among people. What Confucius and Mencius valued resonates with Chiara's ideal, derived from the Gospel: "love your neighbour as yourself" (Matt 19:19). Brotherhood, as conceived by Confucius and Chiara's idea of fraternity, demonstrate clear similarities ${ }^{10}$. In Chiara's view, dialogue can be an effective means towards fraternity ${ }^{11}$; for Confucius, the route to brotherhood is virtue, modesty and behaving in accordance with Chinese cultural standards ${ }^{12}$.

${ }^{8}$ In the past, many Asian countries have their roots in Chinese culture - including Vietnam, Japan, South Korea, Taiwan, Singapore, Malaysia, Hong Kong, and Macao. All these countries were more or less culturally or politically influenced by Confucianism, Buddhism, and Taoism, and thus treated as part of the Sino sphere (Confucian World, Chinese Cultural Sphere) [See Li Xianhai, "From the Rising of Asian Value to the Contemporary Meaning of Confucianism", Academic Monthly 2 (2006): 53-54].

${ }^{9}$ In ancient China, only brotherhood was mentioned, because women were under the control of men; but this notion should be expanded to be brotherhood and sisterhood at this age.

${ }^{10}$ The tradition fraternité, which originated with the French Revolution, was adopted and used by Chiara with a specific Christian significance.

${ }^{11}$ Lubich, Essential Writings, 359.

12 See Confucius, Yanyuan, in Analects, in: Chinese Text Projects. https:/ctext.org/ analects/yan-yuan/. In this chapter, the pupil of Confucian, Yan Yuan, presented a dialogue between Si Ma Niu and Zixia about the path towards brotherhood. The dialogue is as following: Si Ma Niu, full of anxiety, said, "Other men all have their brothers; only I have not." Zi Xia said to him, "There is the following saying which I have heard - 'Death and life have their determined appointment; riches and honors depend upon Heaven.' Let the superior man never fail reverentially to order his own conduct, and let him be respectful to others and observant of propriety - then all within the four seas will be his brothers. What has the superior man to do with being distressed because he has no brothers?" 


\section{1. "Dialogue", in the Thought of Chiara Lubich}

The notion of "dialogue" playing a crucial role in communication, exists both in Western and Chinese philosophy. In Western culture, the notion of "dialogue" is mostly connected to the philosophical field. It can take the form of pure debate, or be a kind of tool for argument that is also "leaving intact the amusing element of character-drawing"13. Written and oral dialogues have diverse functions. The written form is "an enduring literary form in the history of philosophy" that takes place often between two persons ${ }^{14}$. Oral dialogue has multiple functions: it can be an instruction, a means of "deciding two opposite views, of exchanging views, of tackling a particular problem in cooperation with others, of persuading others for reaching a decision"15. Plato treated "dialogue" as an independent literary form; Aristotle followed Plato's concept of dialogue; Socrates used dialogue as a format for speech and discussion ${ }^{16}$. In ancient China, Confucius relied heavily on the oral form of dialogue to teach his pupils - first he would present the "instructional practice", then his words would be written down by his disciples ${ }^{17}$.

In the 20th century, Plato's dialogic tradition remains relevant. The term "dialogue" is used not only in the field of philosophy, but also in the diverse fields of education, social networking, culture and theology. "Dialogue" is used as a practice in a variety of settings and has captured the attention of an increasing number of thinkers - including Mikhail Bakhtin and Martin

${ }^{13}$ Edmund Gross, "Dialogue", in: Encyclopedia Britannica, vol. 8, ed. Hugh Chisholm (Cambridge University Press, 1911), 156-157.

${ }^{14}$ See Karl L. van der Leeuw, "Philosophical Dialogue and the Search for Truth", Thinking: The Journal of Philosophy for Children 3 (2004): 2.

15 Ibidem.

16 Plato and Socrates used both oral and written forms of dialogue for different purposes and functions (see Leeuw, "Philosophical Dialogue", 2-3). Some French Philosophers contributed to constructing the theory of dialogue, such as Fontenelle (1683); in 1688, Nicolas Malebranche published Dialogues on Metaphysics and Religion (reprinted by Cambridge University Press, 1977); see also Mason Gross, Philosophy, Science and Higher Education (Piscataway: Transaction, 2002).

17 The oral form of dialogue used by Confucius was clearly apparent in Analects (Lunyu 論語), which narrated the interactions of his teaching and learning through dialogues with his pupils. See Ma Shingyi (馬行誼), “Classic Annotation of Education in Confucian Analects" (lunyu zhong de jingshi quanshi zhijiao 《論語》中的經史詮釋之教), Journal of Language and Literary Education (yuwen jiaoyu xuebao diyi qi 語文教育學報第一期) 1 (2013): 61 . 
Buber - who have "articulated a holistic concept of dialogue as a multi-dimensional, dynamic and context-dependent process of creating meaning"18. Among them, Martin Buber's theory of dialogue is innovative in that he treats dialogue not as a purposeful effort to reach consensus, like philosophers in the Platonic tradition, but as an authentic expression of relationships among people, as well as between humans and God. This kind of "true dialogue" is characterised by openness, honesty, and mutual commitment ${ }^{19}$.

Martin Buber's interpretation of dialogue offers a new way of thinking about the concept. Dialogue need not be just a way of persuading others to accept some kind of truth; instead, it has the potential to establish real cooperation, mutual love and communion.

Chiara's description of dialogue is close to Martin Buber's notion of it as openness, mutual love and commitment:

Dialogue is a word especially suited to our time. Dialogue means that people meet together and even though they have different ideas, they speak with serenity and sincere love toward the other person in an effort to find some kind of agreement that can clarify misunderstanding, calm disputes, resolve conflicts, and even at times eliminate hatred ${ }^{20}$.

She treats dialogue as the most important way to achieve unity. Even among different cultures and religions, openness for dialogue can help us to "empty ourselves completely, that we put aside from our mind our ideas, our hearts, our affections, our wills and everything we want to do, in order to identify with the other person" 21 . At the same time, Chiara mentions the writings of Pope John Paul II, Crossing the Threshold of Hope, in which he describes the way to achieve unity: through plurality ${ }^{22}$. And for Chiara, the way to achieve unity among people and diversity is mutual love ${ }^{23}$. Mutual love

${ }^{18}$ Louise Phillips, The Promise of Dialogue: The dialogic turn in the production and communication of knowledge (Amsterdam: John Benjamins, 2011).

${ }_{19}$ Martin Buber, Between Man and Man (Eastford: Martino Fine Books, 2014), 129; Samuel Hugo Bergman, Dialogical Philosophy from Kierkegaard to Buber (New York: SUNY Press, 1991), 219.

${ }^{20}$ See Lubich, Essential Writings, 340.

${ }^{21}$ Ibidem, 340-341. Chiara extended her idea about dialogue into the context of different religions, which is prominent for the Focolare Movement.

22 John Paul II, Crossing the Threshold of Hope (New York: Knopf, 1995), 167.

${ }^{23}$ Lubich, Essential Writings, 328. 
leads to the realisation of unity ${ }^{24}$; and in unity, people build a real and new relationship ${ }^{25}$.

Chiara's idea about dialogue was first put into practice within the Christian community. She hoped to build an ecumenical spirituality among the churches. Later, she became aware that unity and mutual love could bind all people who live this spirituality into one, regardless of their cultural background or religion: "by means of this spirituality, people will be able to offer them the witness of the unity we can already achieve... if we Christians love as his spirituality teaches, we would have greater light to see and discover in other religion and cultures the seed of the Word"26. Chiara proposed that non-Christian religions and cultures often reflect a ray of that Truth which Christ revealed, and this discovery can bring us closer together and lead to mutual understanding 27 . "Dialogue" in Chiara's thought should be $360^{\circ}$ dialogue - that is, a kind of omni-bearing dialogue ${ }^{28}$ whose principles are unity, fraternity and mutual love; the "spirituality of communion generates a new way of life" that can build unity and fraternity among us ${ }^{29}$.

\section{Pedagogy of Fraternity: A New Way for Education}

Chiara did not formulate her own theory of education; she simply emphasised the key concepts of creating dialogue and building fraternity, and the importance of unifying Christians with different cultures and religions. Another concept that she considered crucial to building unity and fraternity is communion. In her view, the spirit of communion arises with the pres-

${ }^{24}$ Ibidem, 330.

25 Ibidem, 338.

${ }^{26}$ Ibidem, 331. Chiara has adopted this thought from decree Ad Gentes by Second Vatican Council. In ch. 2, "Mission Work Itself", article 3: "Forming a Christian Community", no. 15. See http://www.vatican.va/archive/hist_councils/ii_vatican_council/documents/vat-ii_decree_19651207_ad-gentes_en.html [accessed 5 June 2018].

27 Second Vatican Council, Nostra Aetate, no. 2, http://www.vatican.va/archive/hist councils/ii_vatican_council/documents/vat-ii_decl_19651028_nostra-aetate_lt.html [accessed 5 June 2018].

${ }^{28}$ Chiara's idea and practice about dialogue were called a $360^{\circ}$ dialogue - which includes not only dialogue with various Christians of every kind, but also deep relation with believers of other religions and cultures, "that is, one that encompasses partners of every kind of belief" [Lubich, Essential Writings, 320].

${ }^{29}$ Ibidem, 338. 
ence of Jesus in the midst of two or more persons; and unity is rooted in communion $^{30}$. Addressing the Catholic Charismatic Conference on the topic of Communion of the Ecclesial Movements in the Third Millennium, she underlined the importance of "making the Church the home and the school of communion" "31. She deeply supported Pope John Paul II's explanation of communion: "Communion (koinonia) embodies and reveals the very essence of the mystery of the Church. Communion is the fruit and manifestation of that love which springs from the heart of the Eternal Father and is poured on us through the Spirit which Jesus gives us (Rom 5:5) to make us all one heart and one soul (Acts 4:32)"32.

Chiara values the idea of communion in her five dialogues - within the Catholic Church, with Christian Churches, with world religions, with persons who have no religious affiliation, and with different cultures. In her view, all these dialogues - as well as the idea of the Focolare Movement - were "in God, the design was in heaven. Even with our most optimistic predictions we never could have imagined that we would see the progressive coming together of this people" 33 . Following God's will, Chiara built unity among Christians, different cultures and religions. She stresses the value of establishing unity and fraternity here on Earth, so that human communion can flourish. Through building fraternity, humans can live in unity, and thus become purified and enlightened ${ }^{34}$. Chiara's philosophy of communion, unity and fraternity has influenced various dimensions, including theology, politics, economy, interreligious dialogue, art and media, cultural studies; and, last but not least, education.

Contemporary scholars have begun to explore Chiara's thought and its contribution to various disciplines. In the field of education, Thomas Masters, Editor-in-Chief of the U.S. New City Press, has written an article, "In Pursuit of Education's Highest Aim: Re-imagining Education through a Spirituality of Communion", ${ }^{35}$ to explain how the context of education could benefit

${ }^{30}$ Chiara Lubich, Jesus in Our Midst (Manila: New City Press, 2003), 22-23.

31 Lubich, Essential Writings, 320.

32 Ibidem, 321.

33 Ibidem, 338

${ }^{34}$ Ibidem, 37.

35 This presentation by Thomas Masters at the 2014 international conference Patterns of Unity: An Interdisciplinary Dialogue on the Thought of Chiara Lubich (1920-2008) is published in Michael James, Thomas Masters, Amy Uelmen (eds.), Education's Highest Aim: Teaching and Learning through a Spirituality of Communion (New York: New City Press, 2010). The 
from Chiara's spirituality. Describing a teacher trained in the spirituality of the Focolare Movement, he narrates her response to chaotic circumstances in society in America: "she could not teach and the students could not learn unless they could establish reciprocity - what in Confucian thought would be called 'human-hearted' relationships" ${ }^{36}$. Thomas Masters agrees that "such relationships are the fundament for unity in any educational setting" ${ }^{37}$.

In her speech during the conferral of an honorary doctorate in education in Washington DC, 2000, Chiara described two fundamental goals of education ${ }^{38}$ : "to teach the individual" and "to build the community" 39 . She also mentioned de facto fundamental methods for education. In her opinion, education could be defined as "the itinerary that a subject (either singly or as a community) pursues with the help of one or more educators, moving to a goal considered worthwhile both for the individual and for humanity" 40 . And the characteristic elements of the educational method to emerge from the main points of the spirituality that guides Focolare members are God as Love, Word of God, and Jesus forsaken ${ }^{41}$. God as Love, as our Father, is "the educator par excellence. He accompanied us, renewed us and gave us new life"42. Word of God means "teach everything to everyone"43. Chiara describes Jesus forsaken as follows:

Jesus cried out, "My God, my God, why have you forsaken me?" (Matt 27:46) $[\ldots] \mathrm{He}$ is the figure of those who are ignorant $[\ldots]$ he is the figure all who are most needy, or maladjusted, or disabled; of those who are unloved, neglected

Chinese translation of this article was recently published in the book of the same name edited by Sonja Huang Mei Tin and Philipp H.U. Kungtze (Xinzhuang: Fu Jen Academia Catholica, 2018). The volume compiles 14 articles related to theology, economy of communion, psychology, media, culture studies, education, marine engineering, and translation studies.

${ }^{36}$ See Thomas Masters, "In Pursuit of Education's Highest Aim: Re-imagining Education through a Spirituality of Communion”, Monthly Review of Philosophy and Culture 10 (2013): 121. For the Chinese version of this article, see Patterns of Unity (Xinzhuang, 2018), 75.

37 Ibidem.

38 This address was given on 10 November 2000 at the Catholic University of America, Washington DC. See Lubich, Essential Writings, 219.

39 Ibidem, 223.

${ }^{40}$ Ibidem, 219.

${ }^{41}$ Ibidem, 219-221.

42 Ibidem, 219.

43 Ibidem, 220. 
$[\ldots]$ however, Jesus forsaken - who went beyond his own infinite suffering and prayed: Father, into your hands I commend my spirit” (Luk 23:46) ${ }^{44}$.

In Chiara's opinion, Jesus forsaken is relevant to educators in that it encourages them to fulfill their mission consistently, despite any difficulties they encounter: "Jesus forsaken is our secret, our key idea, in education as well. It points to the 'limit without limits' that should characterise our educational work" 45 . This requires "educating to face difficulty - which involves commitment on the part of both the educator and the one being educated" 46 . All these methods proposed by Chiara offer a new way for the educator "to teach the individual" and "to build community and unity".

What could Chiara's thought contribute to the field of education nowadays, especially in the context of Chinese culture? First, we need to retrace the development of education. The 20th century saw an emphasis on the "teacher-centred classroom with compartmentalised curriculum and students working independently to memorise facts. The teacher operated as the 'sage on the stage', the giver of all knowledge" ${ }^{\prime 4}$. Diversity among students, and their creativity, were normally ignored. Some education theorists noticed the disadvantages of this approach and developed divergent education theories, providing new concepts and ways to improve the quality of the educational curriculum and its delivery:

- Lev Vygotsky (1896-1934), a Soviet psychologist, contributed a new theory of consciousness that related to the development of "higher psychological functions". He treated human psychological development as "emerging through interpersonal connections and actions with the social environment" 48 . His notion of the "zone of proximal development" became a crucial component of the development of new paradigms in developmental and educational psychology.

- Jean Piaget (1896-1980) was a psychologist and epistemologist whose main contribution focused on child development. A pioneer of

${ }^{44}$ Ibidem, $221-222$.
${ }^{45}$ Ibidem, 221.
${ }^{46}$ Ibidem, 222 .
${ }^{47}$ See https://www.calvary.edu/comparison-20th-21st-century-education/. Calvary University conducted research into the differences between school education in the 20th and 21 st centuries.

${ }^{48}$ See https://en.wikipedia.org/wiki/Lev_Vygotsky [accessed 11 April 2018]. 
the constructivist theory of knowing, he paid much attention to what he called the "schema" - that is, what the child already knows - and how new knowledge could be connected to this schema ${ }^{49}$.

- Burrhus F. Skinner (1904-1990) focused on behaviourism, in which positive reinforcement strengthens behaviour or increases the likelihood of good behaviour being repeated ${ }^{50}$.

- Jerome Bruner (1915-2016) promoted the "spiral curriculum", in which children tackle challenging topics in an age-appropriate way and topics are expanded from one year to the next ${ }^{51}$.

- Benjamin Bloom (1913-1999) was an educational psychologist who developed a classification of educational objectives and formulated a theory of learning that starts with knowledge and grows in complexity towards an evaluation of mastery ${ }^{52}$.

- Howard Gardner (1943-) is a developmental psychologist who is best known for the theory of multiple intelligence. He believed that "the conventional concept of intelligence was too narrow and restrictive and that measures of IQ often missed out on other 'intelligences' that an individual may possess" ${ }^{\prime 53}$.

- Jacques Maritain (1882-1973) was a Catholic philosopher who is best known for his theory of the nature of education. His important educational work, Education at the Crossroads (1942), emphasises the importance of a liberal education: in his view, the goal of education is to cultivate individual authenticity. He believed that there is a kind of dynamism among students, through which students learn from each other and the teacher simply assists this learning process ${ }^{54}$. These educational theories mostly relate to encouraging each student to become mature and independent, in thought and deed ${ }^{55}$; "freedom" and "indi-

49 See https://en.wikipedia.org/wiki/Jean_Piaget [accessed 11 April 2018].

${ }^{50}$ See https://elearninginfographics.com/6-education-theorists-teachers-know-infographic/ [accessed 11 April 2018].

${ }^{51}$ Ibidem.

52 Ibidem.

${ }^{53}$ See https://www.verywellmind.com/howard-gardner-biography-2795511 [accessed 10 September 2018].

${ }^{54}$ See Jacques Maritain, Education at the Crossroads (New Haven, CT: Yale University Press, 1966).

${ }^{55}$ The list is not exhaustive: more recent education theories may have been developed since this article was prepared. 
viduality" were two important concepts that these educators and theorists hoped to instil.

The 21 st century saw the evolution of education to keep pace with rapid changes in society, technology, cultural values and globalisation. The teacher-centred classroom gave way to the student-centred classroom in which teachers accept the role of facilitators ${ }^{56}$. Their main task is not to control, to teach, but "to guide"; this indicates how much more open the education system has become ${ }^{57}$.

How open should the education system be, and what dilemmas does it face in the 21 st century? The UNESCO Principal Regional Office mentioned that the 21 st century presented new choices for education, with global changes having both positive and negative impacts on education. On the positive side are "knowledge explosion, notably science and technology... on the negative side are problems of mortal danger to mankind, such as science and technology applied to destructive purpose; environmental degradation, and a crisis of human value" ${ }_{58}$. This argument presented de facto global problems that we now face, whether in society or in education. Technology has brought progress, but has also created distance between people. Improvements to the education system have helped students to become more independent and individual, but it is hard for them to focus on those close to them. The development of high technology and globalisation have resulted in a world where individualism, materialism and relativism have begun to alienate people from each other.

Relationships formed in such a high-tech era can lack the fundamental elements of fraternity: love and dialogue. How to solve these problems? Chiara's ideal could be treated as an important choice to be explored in the classroom, because she values the importance of fraternity, dialogue and unity - which can contribute positively to society, as well as to education. The function of education is not only to teach a person to be a mature individual, but also to facilitate their relationship-building with others. If students can trust and cooperate with each other, then their diverse aptitudes could help each individual to have a more well-rounded approach to life. Once fraternity and unity are established among them, they will continue to influence each

56 See https://www.verywellmind.com/howard-gardner-biography-2795511 [accessed 10 September 2018].

57 See Raja Roy Singh, Education for the Twenty-First Century: Asia Pacific Perspectives (Bangkok: UNESCO Principal Regional Office, 1991), i.

${ }^{58}$ Ibidem, ix. 
other's lives. Such an approach to education might effectively counter the current predominance of individualism at the expense of society. Yet while Chiara talked about fraternity, unity and love, she did not use the term "pedagogy of fraternity". How could her ideal be expanded into a potential new terminology and pedagogical model? Two narratives illustrate this.

First, Chiara's name was chosen as the name of a kindergarten in southern Italy, because the school aimed to put into practice a pedagogy of fraternity and love for the youngest and humblest. Ezio Aceti, a psychologist, considered Chiara an excellent educator. His decision to name the school after Chiara was based on the desire to make "its pedagogy be inspired by the value of fraternity, that is expressed in the teaching methodology by the ability to transmit disciplinary knowledge to the youngest ones" 59 . For him, Chiara is the perfect example of this. Her approach encourages the educator to value the Gospel and actively help the students to build fraternity in their community. In Ezio's mind, Chiara's spirituality and charism are for the present and don't pass away even if the foundress of the Movement is no longer with us ${ }^{60}$.

Second, Sophia University Institute - founded in 2007 by the Focolare Movement - offers a master's degree in "Foundations and Perspectives of a Culture of Unity" and a corresponding doctorate degree. It describes itself as "a community of training, study and research to which everyone contributes through exercise of their respective skills and responsibilities - the faculty, the students and the personnel"61. Each student is in a dynamic ongoing

${ }^{59}$ See http://www.focolare.org/en/news/2014/02/18/scuola-dellinfanzia-intitolata-a-chiara-lubich/ [accessed 12 April 2018], which explains the full story about naming this school after Chiara. Apart from Chiara, Aceti mentions other personalities who proposed a new educative style - such as French philosopher Simone Weil, who described paying attention as a "form of love for the neighbor who is speaking". Aceti suggests that Martin Buber, the Jewish philosopher, "exhorted to put oneself in the shoes of the other, to listen following the inspirations that come from this and finally to communicate them to the other". The Italian educator, Maria Montessori, elaborated a system of teaching which showed that "if it is possible to teach something to a child bearing a handicap, then it is possible to teach it to all the children". Janusz Korczak, the Polish educator, accompanied the children in his orphanage up to the moment of their death in the concentration camp of Treblinka.

${ }^{60}$ Ibidem.

${ }^{61}$ See http://www.focolare.org/en/works-and-activities/studio-e-formazione/istituto-universitario-sophia/ [accessed 12 April 2018]. Sophia University Institute was erected by the Holy See by decree of the Congregation for Catholic Education on 7 December 2007. It is located in Loppiano, Italy. The faculty consists of 30 university professors from various countries and 
relationship with the others, appreciating the contribution of various methods and individual approaches, and diversity of knowledge, to the construction of a new and more integrated worldview ${ }^{62}$. Sophia University Institute is where Chiara's ideal, "Be a family... to love one another until all may be one", has been put into practice in education.

Inspired by Chiara's philosophy, these two educational establishments have developed an innovative educational style ${ }^{63}$ that focuses on mutual love and relationship among students - aspects that have been generally overlooked in other approaches to educational theory and practice.

Could Chiara's thoughts on education be put into practice in Asia? An experiment was carried out in Taiwanese higher education, where a course named "Culture of Unity" - inspired by Chiara - was offered with the aim of teaching the concepts of unity and fraternity. This case study will explore how the theory of pedagogy of fraternity could potentially work, and what kind of outcome it might have in an Asian context.

\section{Course: Culture of Unity in Higher Education in Taiwan ${ }^{64}$}

As already mentioned, Chiara's ideals have some similarities with Chinese culture: the notions of unity and fraternity are also cherished by people with a Chinese cultural background. But could Chiara's culture of unity be applied in the classroom in the context of Asian culture, and be accepted by students to the point of influencing their perspective on life? In 2017, based on Chiara's spirituality, Fu Jen Catholic University in Taiwan offered a course named "Culture of Unity." It was a novel experiment for the university, where most students were completely unfamiliar with Chiara Lubich and the Focolare Movement. The University offered the course in the hope that young students in Taiwan could become aware of the importance of unity and fraternity. It was anticipated that, once familiar with the concept

experts in various disciplines including theology, philosophy, ethics, law, political science, economy, linguistics, literature, natural science, mathematics, communication science, fine arts, ecumenism, and interreligious dialogue.

${ }^{62}$ Ibidem.

${ }^{63}$ There are currently few educational institutions inspired by Chiara's spirituality.

${ }^{64}$ The "Culture of Unity" course was delivered by the author of this article. 
of unity, they would go on to put it into practice in their learning as well as in their daily life.

It was not easy to promote this course, which the university side categorises as Catholic spiritual practice. Although Fu Jen is a Catholic University with a strong focus on spiritual topics, the academic side tries not to interfere with the curriculum arrangement of each department. This course was affiliated to the Department of Religious Studies, where all courses on offer must be approved by the curriculum committee whose members are mostly non-Christian. The course received committee approval in 2017, and started officially in September that year as an 18-week semester course of 2 hours each week; student ages ranges from 21 to 70 years ${ }^{65}$. Course preparation required some difficulties and challenges to be taken into account - such as students' religious background. Normally, the Catholic catechism should be avoided in a non-religious course, where it is considered inappropriate for teachers to talk about religious teaching or recommend a specific religious community. Given these considerations, the course was finally designed to simply introduce the notions of unity and fraternity and their relation to the other disciplines, then guide the students towards putting these two concepts into practice. It was hoped that students would acquire an understanding of the importance of the "culture of unity" and try to build fraternity in the classroom, so that these ideals could be transferred to their homes and workplaces. The course arrangements are described below.

\section{"Culture of Unity" Course Curriculum}

Week 1: Introduction

Week 2: What is the "Culture of Unity"?

Week 3: Do We Need Unity Nowadays?

Week 4: Culture of Unity and Young People

Week 5: Culture of Unity and Art

Week 6: Culture of Unity and Other Religions I

Week 7: Culture of Unity and Other Religions II

Week 8: Culture of Unity and Economy of Communion I

Week 9: Culture of Unity and Economy of Communion II

${ }^{65}$ This course was offered as a single-semester course in which some students were older than 65 . Unity therefore had to be introduced in a way that was suitable for all age levels. 
Week 10: Mid-term Exam

Week 11: Culture of Unity and Environment

Week 12: Culture of Unity and Media

Week 13: Culture of Unity and Different Cultures

Week 14: Workshop: How do I Live Culture of Unity and Fraternity in My Daily Life?

Week 15: Culture of Unity and Education

Week 16: Culture of Unity and Chinese Culture: A Discussion

Week 17: Unity and Fraternity as an Action I

Week 18: Unity and Fraternity as an Action II: Final Report.

Importantly, the teacher of this course had a background in the Focolare Movement; she values Chiara's spirituality and hoped to put it into practice in her classroom and workplace. In her opinion, the course was difficult at first because the students had no understanding or experience of unity and fraternity; they were clearly unfamiliar with Chiara Lubich and her ideas. But as Asian people they already know the importance of family, because Asian society is family-oriented. Therefore, the teacher spent four weeks helping the students to appreciate that mutual love, unity and fraternity are crucial for any community, whether a family or a classroom: the students are expected to treat each other as family, even outside class - indeed, some activities were designed for this very purpose.

Chiara's notion of unity was discussed in class and comparisons were made with the corresponding concept in Chinese culture, so that the students could understand Chiara's ideal better through their own cultural background $^{66}$. After four weeks of practice, the students tried to engage in dialogue, discussion, and practice of mutual love with the other students. Some changes became apparent: students who rarely smiled to other classmates began smiling and actively greeting each other. At this state, they may not have been fully aware of the deeper meanings of unity and fraternity, but they were already experiencing mutual love among them. They liked to gesture "1" by raising a finger as a symbol of unity. They understood that wherever they might be, they would be connected through their unity and mutual love. Unity became their common language.

After four weeks, the ideal of unity and its relation to other aspects were further introduced. While the students did not fully grasp all the aspects of

${ }^{66}$ Chinese culture has a similar concept: the unity between humanity and heaven（天人 合一) is often mentioned in ancient Chinese philosophy. 
unity and its relation to other disciplines, they enjoyed exploring its relation to other religions, cultures and disciplines, such as "Economy of Communion" (EoC) - started in 1991 when Chiara visited Brazil, this was a popular initiative among students with the mission statement "No one should be in need" ${ }^{\prime 67}$. The students were amazed to discover numerous projects deriving from EoC's "culture of giving", sharing one-third of profits with the poor. The topic of interreligious dialogue and unity was also very popular with the students.

Understanding and building unity in the class presented challenges for the students, too. In discussion, they often expressed scepticism about building unity among themselves and among different religions and cultures. They did not believe that the idea of EoC could be put into practice, because they felt few people would be willing to share their profits with others. Nevertheless, despite this perceived reluctance, in the classroom, each student was still willing to share their experiences of putting these ideas into practice. This all demonstrates that they could indeed build unity, and willingness to give, among the people they met. From the introduction and class discussion, the students acquired a profound understanding that it was possible to build unity and fraternity in every aspect of daily life. Some members, inspired by the Focolare Movement, were invited to investigate every facet of unity and its possible influence on different disciplines; for example, one guest speaker talked about the "Unity and the Media", another shared her experiences of unity shaping interreligious dialogue, and so on. The course gave equal importance to theory and practice. Normally, one aspect of it would be introduced in class, and then discussion and sharing experiences would follow; finally, the concept would be summarised and clarified to reinforce learning.

By the mid-term exam, the students were treating each other more and more like brothers and sisters. They shared their experiences and difficulties they had encountered when "living unity" each week, and encouraged each other to keep going. Fraternity was clearly established among them: they helped their classmates and actively kept in touch with each other. In their final report, some students explored issues such as unity and the environment,

${ }^{67}$ See Lubich, Essential Writings, 274-275. According to the idea of EoC, profits would then be used for the common good. "One part would be used for the same goal as the early Christian community; to help the poor by providing for their need until they found work. Another part, to develop structures to form 'new people', that is, people formed and animated by love, capable of living out what we call the 'culture of giving'. The last part, of course would be used for the growth of the company" [Ibidem, 275]. 
unity and EoC, unity in the family. The narratives of two students were particularly touching: the first, 45 years old, had been having problems with his wife for some time. He said that having learned the importance of unity and how to build it in the classroom, he wanted to put it into practice at home. Aware that unity is crucial in the family, he made his first step to love his wife and apologised for all his wrongdoings that had hurt her. His relationship with his wife had been transformed by this dialogue, which had restored harmony and unity; he felt peaceful and happy at last. The other student described a difficult relationship with her mother; since sharing with her the ideal of unity that she had learned in class, they had both been making an effort to live together in unity.

Both students were giving poignant examples of how "true dialogue" with their family became possible when they began putting into practice at home what they had learned in class. These presentations were well received by their classmates, who enthusiastically responded with the "1" (unity) gesture.

\section{Conclusion}

Evaluating this course, there are no doubt some parts that could be done better - for example, the theory should be examined; the practice could be analysed in detail. Could Chiara's ideas be constructed as a new theory of pedagogy, namely pedagogy of fraternity? Her spirituality certainly offers potentially new approaches to education, but the construction of theory from her ideas would require more statistical analysis based on the outcomes of using her ideas in the classroom. The results from this 18 -week course exceeded the teacher's expectations and had a high acceptance rate among the students, whom it influenced positively. Most students in this class understood the ideals of unity and fraternity and were keen to put them into practice during and after the course, although they were less familiar with Chiara Lubich and the Focolare Movement. This offers encouraging evidence that Chiara's spirituality could be accepted officially and put into practice in the classroom, especially in the higher education system, as well as making a positive impact on students' outlook on life. A one-semester course is inadequate to draw definitive conclusions about Chiara's ideas and the outcome of their practice in the classroom.

Feedback from the students, however, has been encouraging. The course has been scheduled to re-run from September 2019, and most of the students who were in this class in 2017 chose another course offered by this teacher in 
the second semester that year. Delighted to see her former students again, the teacher asked why they had chosen this new course. The students answered that they hoped to revisit the atmosphere of fraternity and unity they had experienced in the "Culture of Unity" course, although the next course was on a different topic ${ }^{68}$. This supports the view that Chiara's ideals did help higher education students to start paying closer attention to the importance of dialogue and building unity - not just within the classroom, where they have come to see each other as brothers and sisters, but back at home with their own families. The students' responses indicate their shared need to love and be loved. As Chiara put it, "We would not have any meaning in the world if we were not a little flame of this infinite fire: love that responds to love" 69 .

The "Culture of Unity" course offers a way to build unity and fraternity, as demonstrated by this class. Does this mean that Chiara's ideas about education fit the needs of this specific field? Given the development of education theories, it is apparent that the key challenges of education change over time. From a teacher-oriented strategy in the 20th century to a student-centred strategy in the 21 st century, the education environment has clearly changed from closed to open. Educators now focus on guiding students to be open and acquire critical thinking, since it leads them towards individuality. Social circumstances have changed; educational strategies have changed; students have changed. Faced with all these changes, educators must use reflective thinking to balance potentially conflicting demands in the classroom and achieve their educational goals ${ }^{70}$. What do educators hope to achieve in the classroom? The answers might vary from one to another.

Today's world faces economic crises resulting from globalisation, as well as environmental and moral problems ${ }^{71}$ People no longer lack the knowledge, technology or ambition to seek their fortune; but these are not the goals that education hopes to achieve. Besides seeking expertise, education has still a responsibility to nurture humanity in a holistic way. American philosopher

${ }^{68}$ The "Culture of Unity" course was offered in the first semester. In the second semester of 2017, the same teacher offered a different course: "Religious Images and Religious Miniatures".

${ }^{69}$ See Crescencia C. Gabian, Dialoge, Light and Fire: Chiara Lubich and the Spirituality of Unity (Manila: University of Santo Thomas, 2017), 7.

${ }^{70}$ See Chee Choy and San Oo Pou, "Reflective Thinking and the Teaching Practice: A Precursor for Incorporating Critical Thinking into the Classroom?", International Journal of Instruction 1 (2012): 168.

${ }^{71}$ See Joseph Stiglitz, "The Global Crisis, Social Protection and Job", International Labour Review 1-2 (2009): 2. 
Martha Nussbaum explained that humanity could be cultivated by developing three capacities: "the capacity for critical self-examination and critical thinking about one's own culture; ... the capacity of seeing oneself as a human being who is bound to all human with ties of concern; ... and the narrative imagination" "72. The second of these, in my opinion, is essential for modern education and also finds some overlap in Chiara's thought. Chiara goes further, in explaining the methods to achieve it. In her talk, "What is Essential Today?", she expressed the view that what today's generation has been waiting for is "God-Love, believing in his love, responding to his love by loving, these are the great imperatives today... without it the world is heading for destruction, like a train off the tracks" ${ }^{\text {"73. }}$. Only through loving each other can true dialogue and relationship be built.

Chiara's point of view and methods for practice differ from many education theories today. Her perspectives on education are combined with Christian faith: for her, the best educator is Jesus. For Chiara, fulfilling Jesus' prayer "May they all be one" is already an educational process: "It is through this educational process that we as individuals and as community become capable of meeting with, entering into dialogue with, and working together

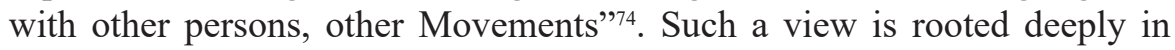
her Christian faith; students with a Chinese cultural background might not completely grasp Chiara's spirituality. But the key concepts she raised - unity, fraternity, love and dialogue - are well established for Chinese culture, which already has similar ideas deriving from Confucianism. This is what makes Chiara's spirituality meaningful for the higher education field in Taiwan, as well as for Asian cultures more generally.

Building fraternity and unity in the classroom has not traditionally been considered a key goal of education. The "Culture of Unity" course might offer an opportunity for students and teacher alike to experience the potential benefits of a new dimension in education. Yet this is just a start: to continue developing Chiara's pedagogy of fraternity and putting it into practice, a better methodology and model are required. New inspiration might emerge when the course is repeated; and collective input into the curriculum design is anticipated in the near future. In the meantime, this experimental course sup-

72 Martha C. Nussbaum, Cultivating Humanity: A Classical Defense of Reform in Liberal Education (Cambridge, MA: Harvard University Press, 1997), 9-10.

${ }^{73}$ Lubich, Essential Writings, 56.

${ }^{74}$ Ibidem, 224. 
plies clear evidence for a new way forward in education, based on Chiara's ideal of unity and her pedagogy of fraternity.

\section{References}

Bergman, Samuel Hugo. Dialogical Philosophy from Kierkegaard to Buber. New York: State University of New York Press, 1991.

Buber, Martin. Between Man and Man. Eastford: Martino Fine Books, 2014.

Choy, Chee, San Oo Pou. "Reflective thinking and the Teaching Practice: A Precursor for Incorporating Critical Thinking into the Classroom?". International Journal of Instruction 1 (2012): 167-182.

Flecha, Ramón. Sharing Words: Theory and Practice of Dialogue Learning. MD: Rowman and Little field, 2000.

Gabian, Crescencia C. Dialoge, Light and Fire: Chiara Lubich and the Spirituality of Unity. Manila: University of Santo Thomas Publishing House, 2017.

Gendron, Louis. "The Background and Meaning of Chiara Lubich's Visit to Taiwan" ( $\mathrm{Lu}$ Jiale laitai de beijing hen Yiyi 盧嘉勒來台的背景和意義). Collectanea Theologica (Shenxue Lunji 神學論集) 111 (2017): 82, 146, 152.

Gross, Edmund. "Dialogue". In: Encyclopedia Britannica, ed. Hugh Chisholm, vol. 8, 156-157. Cambridge University Press, 1911.

Gross, Mason. Philosophy, Science and Higher Education. Piscataway: Transaction Publishers, 2002.

Huang, Sonja Mei Tin. "The Report on the Conference Patterns of Unity: An Interdisciplinary Dialogue on the Thought of Chiara Lubich (1920-2008)". Catholic Weekly (Tienzhujiao Zhoubao 天主教週報) 12.28 April, 2013.

James, Michael, Thomas Masters, Amy Uelmen. Education's Highest Aim: Teaching and Learning through a Spirituality of Communion. New York: New City Press, 2010.

John Paul II. Crossing the Threshold of Hope. New York: Knopf, 1995.

Leeuw, Karl L. van der. "Philosophical Dialogue and the Search for Truth". Thinking: the Journal of Philosophy for Children 3 (2004): 1-14.

Lubich, Chiara. Essential Writings: Spirituality Dialogue Culture. London: New City Press, 2007.

Lubich, Chiara. Jesus in our midst. Manila: New City Press, 2003.

Lubich, Chiara. La Dottrina Spirituale. Milano: Mondadori, 2001.

Malebranche, Nicolas. Dialogues on Metaphysics and Religion. Cambridge: Cambridge University Press, 1977. 
Maritain, Jacques. Education at the Crossroads. New Haven: Yale University Press, 1966.

Masters, Thomas. “In Pursuit of Education's Highest Aim: Re-imagining Education through a Spirituality of Communion". Monthly Review of Philosophy and Culture 10 (2013): 121-137.

Nussbaum, Martha C. Cultivating Humanity: A Classical Defense of Reform in Liberal Education. Cambridge, Massachusetts and London: Harvard University Press, 1997.

Patterns of Unity: An Interdisciplinary Dialogue on the Thought of Chiara Lubich (1920-2008), eds. Sonja Huang Mei Tin, Philipp HU Kungtze. Xinzhuang: Fu Jen Academia Catholica, 2018.

Phillips, Louise. The Promise of Dialogue: The dialogic turn in the production and communication of knowledge. Amsterdam: John Benjamins Publishing Company, 2011.

Singh, Raja Roy. Education for the twenty-first Century: Asia Pacific Perspectives. Bangkok: UNESCO Principal Regional Office, 1991.

Stiglitz, Joseph. "The global crisis, social protection and job". International Labour Review 1-2 (2009): 1-13.

Xianhai, Li. "From the Rising of Asian Value to the Contemporary Meaning of Confucianism". Academic Monthly 2 (2006): 53-58.

Xinyi, Ma. "Classic Annotation of Education in Confucian Analects". Journal of Language and Literary Education 1 (2013): 59-76. 
